Transactions of the American Fisheries Society, 1981, v.110, n.5, pp.604-612.

ISSN: 0002-8487

DOI: $10.1577 / 1548-8659(1981) 110<604: L B P O S T>2.0 . C O ; 2$

http://afs.allenpress.com/perlserv/?request=get-archive

http://afs.allenpress.com/archive/1548-8659/110/5/pdf/i1548-8659-110-5-604.pdf

(C) Copyright by the American Fisheries Society 1981 


\title{
Largemouth Bass Predation on Stocked Tiger Muskellunge
}

\author{
Roy A. Stein \\ Department of Zoology \\ Robert F. Carline and Robert S. Hayward \\ Ohio Cooperative Fishery Research Unit ${ }^{1}$ \\ The Ohio State University \\ 1735 Neil Avenue, Columbus, Ohio 43210
}

\begin{abstract}
To better understand why stocked esocids survive poorly, we estimated mortality rates of tiger muskellunge ( $\mathrm{F}_{1}$ hybrid of female muskellunge Esox masquinongy $\times$ male northern pike $E$. lucius) that were placed into two Ohio reservoirs (mean fish total lengths, 171 and $179 \mathrm{~mm}$; 62 fish per hectare). Because pond experiments showed that hybrids stocked at night experienced mortality rates as high as those released during the day, we stocked tiger muskellunge into lakes during the day. Mortality of stocked hybrids (estimated by catch per effort of electrofishing) exceeded $95 \%$ within 40 days in both lakes. Population estimates of largemouth bass Micropterus salmoides coupled with stomach-content data revealed that these predators accounted for $26 \%$ and $45 \%$ of the numbers stocked in the two lakes. In addition, some hybrids died from thermal stress. Improved survival of tiger muskellunge should result if they are stocked at lengths greater than $250 \mathrm{~mm}$ to reduce predation losses, and late in fall when thermal stress is reduced.
\end{abstract}

The tiger muskellunge $\left(\mathrm{F}_{1}\right.$ hybrid of female muskellunge Esox masquinongy $\times$ male northern pike E. lucius) has been stocked in many freshwater lakes to provide a trophy sport fishery and to control panfish populations (Graff 1978). These hybrids can be cultured economically on artificial dry diets and often grow faster than either northern pike or muskellunge (Schrouder 1973; Weithman and Anderson 1977). However, because they are sterile (Hesser 1978), population maintenance depends on continued stocking. Generally, esocids stocked into lakes and reservoirs have had variable (Johnson 1978) or uniformly low (Belusz 1976) rates of survival. Resident fish predators have been suggested as important influences on survival of stocked esocids (Weithman 1975; Johnson 1976; Weithman and Anderson 1977; Hess 1979, 1980); however, without exception, no one has quantified this source of mortality.

During work in 1979 , nearly all the $100-\mathrm{mm}$ (total length) tiger muskellunge we stocked died within 2 to 4 weeks. On the third night after stocking, $25 \%$ of the largemouth bass

1 The Unit is jointly sponsored by the United States Fish and Wildlife Service, Ohio Department of Natural Resources, and The Ohio State University.
Micropterus salmoides sampled had eaten stocked hybrids. We then designed this study to quantify the importance of predation by largemouth bass on survival of stocked tiger muskellunge. We also compared survival of hybrids stocked at night, when predation and stress might be less (Belusz 1978; Hess 1980), with that of hybrids stocked during the day.

\section{Study Areas}

We compared survival of day- and nightstocked hybrids in Bird's Pond, a 0.8-hectare, privately owned pond in Franklin County, Ohio. Maximum depth was $4 \mathrm{~m}$; aquatic vegetation (Typha spp. and Ceratophyllum spp.) was sparse and confined to depths less than $20 \mathrm{~cm}$ near the pond margin. During two experiments in mid-July, secchi disc readings exceeded $2 \mathrm{~m}$. Dissolved oxygen concentrations were greater than $3.0 \mathrm{mg} /$ liter to depths of $1 \mathrm{~m}$ during the first experiment and $2 \mathrm{~m}$ during the second. Largemouth bass were the only predators large enough to consume stocked fish.

We evaluated largemouth bass predation on stocked tiger muskellunge in two reservoirs in southwestern Ohio (for morphometric data, see Fig. 2). Submersed aquatic vegetation in Acton Lake (Preble County) was nonexistent and less than $5 \%$ of the shoreline was occupied by Typha 
TABLE 1.-Number, size, and transport conditions for hybrid tiger muskellunge stocked into Bird's Pond and Stonelick and Acton lakes.

\begin{tabular}{|c|c|c|c|c|c|c|c|c|c|c|}
\hline \multirow[b]{4}{*}{ Site } & \multirow{2}{*}{\multicolumn{4}{|c|}{ Stocking statistics }} & \multicolumn{6}{|c|}{ Transport conditions } \\
\hline & & & & & \multicolumn{5}{|c|}{ Temperature (C) } & \multirow[b]{3}{*}{$\begin{array}{l}\text { Density } \\
\text { in tank } \\
\text { (g/liter) }\end{array}$} \\
\hline & \multicolumn{2}{|c|}{ Hybrids stocked } & \multicolumn{2}{|c|}{ Mean size } & & Trans] & ort tank & & & \\
\hline & $\begin{array}{c}\text { Total } \\
\text { number }\end{array}$ & $\begin{array}{l}\text { Number } \\
\text { per } \\
\text { hectare }\end{array}$ & $\begin{array}{l}\text { Total } \\
\text { length } \\
\text { (mm) }\end{array}$ & $\begin{array}{c}\text { Wet } \\
\text { weight } \\
\text { (g) }\end{array}$ & Hatchery & $\begin{array}{l}\text { Arrival } \\
\text { at lake }\end{array}$ & $\begin{array}{c}\text { At } \\
\text { stocking }\end{array}$ & $\begin{array}{l}\text { Pond } \\
\text { or lake }\end{array}$ & $\begin{array}{c}\text { Average } \\
\Delta \mathrm{T} \\
{\text { (C/hour })^{\mathrm{a}}}^{2}\end{array}$ & \\
\hline \multicolumn{11}{|l|}{ Bird's Pond ${ }^{\mathrm{b}}$} \\
\hline Experiment 1 & 200 & 250 & 125 & 9 & 19.0 & 24.5 & 26.0 & 28.5 & 2.2 & 27 \\
\hline Experiment 2 & 200 & 250 & 137 & 11 & 17.5 & 20.5 & 25.0 & 28.0 & 2.4 & 33 \\
\hline Stonelick Lake & 4,300 & 62 & 179 & 30 & 19.5 & 21.0 & 27.0 & 30.5 & 4.4 & 80 \\
\hline Acton Lake & 15,625 & 62 & 171 & 26 & 22.8 & 24.0 & 24.0 & 26.0 & 1.1 & 53 \\
\hline
\end{tabular}

a Average rate of change in water temperature in transport tanks, from hatchery to stocking site.

b Experiments 1 and 2 comprised two treatments (day and night releases) of 100 hybrids each.

spp. The only inshore cover was windfallen trees. In Stonelick Lake (Clermont County), abundance of submersed vegetation was also quite low; only two small bays contained low densities of Potamogeton spp. Emergent vegetation (primarily Typha spp.) occupied more than $50 \%$ of the shoreline, but afforded little cover, because water depths in these areas were less than $20 \mathrm{~cm}$; isolated patches of water willow Dianthera americana were common. At stocking, both lakes were stratified; dissolved oxygen concentrations were less than $0.5 \mathrm{mg} / \mathrm{liter}$ at depths below $2 \mathrm{~m}$ in Stonelick Lake and below $4 \mathrm{~m}$ in Acton Lake. Secchi disc readings were $25 \mathrm{~cm}$ in Stonelick Lake and $50 \mathrm{~cm}$ in Acton Lake. No predators, other than largemouth bass, were of a size sufficient to consume stocked hybrids in Stonelick Lake; Acton Lake did have small populations of adult tiger muskellunge, muskellunge, and channel catfish $I c-$ talurus punctatus, which constituted less than $1 \%$ of the predators, based on electrofishing surveys.

\section{Methods}

Tiger muskellunge, reared on a dry pellet diet (W-7 formulation, Orme 1978), were obtained from Kincaid Fish Farm, Ohio. A sample was measured, weighed, and marked or tagged (if necessary) the day before each stocking. Hybrids were transported in aerated tanks. To reduce stress and the possibility of disease, transport tanks contained a mixture of $0.5 \%$ salt and $10 \mathrm{mg} /$ liter terramycin.

To estimate the size of largemouth bass populations, we began Schnabel mark-recapture procedures (Ricker 1975) when hybrids were stocked and continued using these techniques throughout experiments. Fish longer than 200 $\mathrm{mm}$ total length (longer than $150 \mathrm{~mm}$ in Bird's Pond) were captured with a 230-volt pulsed direct-current boom shocker, measured (nearest $1.0 \mathrm{~mm}$ ), fin-clipped, and released.

\section{Day versus Night Stocking}

At Bird's Pond, we estimated predation rates of largemouth bass on tiger muskellunge stocked during the day and at night. In two experiments, 100 hybrids (about $130 \mathrm{~mm}$ total length) each were marked as to treatment (day or night), separately transported from Kincaid Fish Farm, and stocked at either 1300 or 2200 hours. In the first experiment, either the left or right ventral fins were removed. Jaw tags, 10-mm loops of 16-gauge copper or steel wire, were used in the second experiment. Hybrids were similar in length within treatments and between experiments (Table 1).

During transport of hybrids, rates of temperature change between hatchery and pond averaged less than $2.5 \mathrm{C} /$ hour for all treatments (Table 1). Oxygen content of the water in transport tanks always exceeded $5.0 \mathrm{mg} / \mathrm{liter}$. To reduce temperature shock at stocking, pond water was added to the transport tank over the course of about 1 hour until temperatures were within $2 \mathrm{C}$ of pond temperature.

Shore observers and scuba divers documented the distribution of hybrids immediately after the fish were released. At frequent intervals (see Table 3) after stocking each treatment group, we collected largemouth bass with an 
TABLE 2.-Schnabel population estimates of largemouth bass at Bird's Pond and Acton and Stonelick lakes. The 95\% confidence intervals (C.I.) were calculated from fiducial limits for the binomial distribution (Ricker 1975).

\begin{tabular}{lccccc}
\hline \multicolumn{1}{c}{ Site } & $\begin{array}{c}\text { Minimum } \\
\text { total } \\
\text { length } \\
\text { (mm) } \\
\text { marked }\end{array}$ & $\begin{array}{c}\text { Point } \\
\text { estimate }\end{array}$ & $\begin{array}{c}\text { Number per } \\
\text { hectare }\end{array}$ & $95 \%$ C.1. & $\%$ marked \\
\hline Bird's Pond & 150 & 118 & 148 & $75-186$ & 30 \\
Stonelick Lake & 200 & 563 & 8 & $437-789$ & 38 \\
Acton Lake & 200 & 1,352 & 5 & $873-2,985$ & 13 \\
\hline
\end{tabular}

electroshocker, measured them, recorded marks, and flushed their stomachs using techniques described by Seaburg (1957) and Foster (1977). Tiger muskellunge (or wire tags) recovered from stomachs were tabulated by treatment. Numbers $(X)$ of hybrids recovered from individual largemouth bass stomachs fit a negative binomial distribution; therefore, we used a natural $\log$ transformation $\left(\log _{c}[X+1]\right)$ to estimate mean number of hybrids per stomach for each sampling period. In the first experiment, day stocking preceded night stocking; the sequence was reversed in the second experiment.

\section{Hybrid Survival in Lakes}

We stocked tiger muskellunge of similar sizes and at equal densities (Table 1) into Stonelick and Acton lakes at midafternoon on August 26 and September 2, 1980, respectively. Transport conditions were similar for hybrids hauled from the hatchery to the lakes, although the temperature increase was more severe for fish stocked into Stonelick Lake (Table 1).

To determine movement patterns and distribution of hybrids, we seined $(11.5 \times 2 \mathrm{~m}$ bag seine, $4.5-\mathrm{mm}$ mesh) at least five stations around the lake 3 hours poststocking and on each day for 3 days following release. We also electrofished along the entire perimeter of the lake for three consecutive nights after stocking to follow dispersal and survival of hybrids and determine predation rate by largemouth bass. Thereafter, lakes were seined and electrofished weekly until no hybrids were collected. We measured all largemouth bass (longer than 200 $\mathrm{mm}$ ), recorded their marks, pumped their stomachs, and released them. We multiplied estimates of number of tiger muskellunge per largemouth bass stomach (determined from a graph of predation rate and time, see Fig. 1) by the estimated number of largemouth bass in the population to obtain daily estimates of hybrid mortality. Total mortality was estimated from the slope of the relation between time (days after stocking) and natural log of catch per effort of hybrids by electrofishing.

\section{Results}

Mortality immediately after stocking varied among the three study sites. We saw no dead hybrids in Bird's Pond, but 9 dead hybrids were observed within 1 hour after stocking in Acton Lake and 49 in Stonelick Lake. Many daystocked tiger muskellunge jumped and skipped across the water surface, behavior that may be interpreted as a stress response; this was especially pronounced in Stonelick Lake.

\section{Day versus Night Stocking}

In contrast to the active behavior exhibited by day-stocked groups, fish stocked at night moved slowly to the bottom and remained relatively inactive for at least 2 hours. On the day after these stockings we found individual tiger muskellunge close inshore, high in the water column, and motionless, but none offshore.

Estimates of the largemouth bass population in Bird's Pond (Table 2) and stomach contents of this predator (Table 3) suggest that more than $50 \%$ of the day-stocked hybrids were eaten within 8 hours. Darkness hindered predation on the night-stocked group, but during daylight hours night-stocked fish appeared just as susceptible to predators as the day-stocked group. Based on our estimates, all tiger muskellunge were eaten within 48 hours after they were stocked, regardless of when they were stocked. Extensive seining and electrofishing at this time produced no hybrids, supporting our estimates of total mortality.

For each experiment, we estimated that 236 
TABLE 3.-Estimated number of day-and night-stocked hybrid tiger muskellunge ( $\mathrm{N}=100$ stocked per treatment, 130 $\mathrm{mm}$ ) eaten by largemouth bass in Bird's Pond. Day-stocked fish were released first in experiment 1; night-stocked fish were released first in experiment 2. Treatments were differentiated by fin clips in experiment 1 and jaw tags in experiment 2.

\begin{tabular}{|c|c|c|c|c|c|c|}
\hline \multirow[b]{2}{*}{ Treatment } & \multirow[b]{2}{*}{$\begin{array}{c}\text { Hours after } \\
\text { stocking }\end{array}$} & \multirow{2}{*}{$\begin{array}{l}\text { Number of } \\
\text { largemouth } \\
\text { bass } \\
\geqslant 150 \mathrm{~mm} \\
\text { sampled }\end{array}$} & \multicolumn{2}{|c|}{ Geometric mean (numbers) } & \multirow{2}{*}{$\begin{array}{c}\text { Number eaten } \\
\text { per sample } \\
\text { period }\end{array}$} & \multirow{2}{*}{$\begin{array}{c}\text { Cumulative } \\
\text { number } \\
\text { of hybrids } \\
\text { eaten }^{\mathrm{a}}\end{array}$} \\
\hline & & & $\begin{array}{c}\text { Hybrids } \\
\text { per stomach }\end{array}$ & $\begin{array}{c}\text { Jaw tags } \\
\text { per stomach }\end{array}$ & & \\
\hline \multicolumn{7}{|l|}{ Experiment 1} \\
\hline Day stocking & $\begin{array}{r}3.5 \\
10.5\end{array}$ & $\begin{array}{r}5 \\
22\end{array}$ & $\begin{array}{l}0.52 \\
0.41\end{array}$ & & $\begin{array}{l}61 \\
48\end{array}$ & $\begin{array}{r}61 \\
109\end{array}$ \\
\hline Night stocking & $\begin{array}{r}2.5 \\
24.0 \\
48.0\end{array}$ & $\begin{array}{l}15 \\
18 \\
13\end{array}$ & $\begin{array}{l}0.10 \\
0.54 \\
0.11\end{array}$ & & $\begin{array}{l}12 \\
64 \\
13\end{array}$ & $\begin{array}{l}12 \\
76 \\
89\end{array}$ \\
\hline Unknowns & $3.0^{\mathrm{b}}$ & 5 & 0.32 & & 38 & 38 \\
\hline \multicolumn{7}{|l|}{ Experiment 2} \\
\hline Night stocking & $\begin{array}{r}5.0 \\
24.0 \\
48.0\end{array}$ & $\begin{array}{r}11 \\
11 \\
8\end{array}$ & & $\begin{array}{l}0.07 \\
0.31 \\
1.04\end{array}$ & & $\begin{array}{r}8 \\
37 \\
123\end{array}$ \\
\hline Day stocking & $\begin{array}{r}8.0 \\
32.0\end{array}$ & $\begin{array}{r}11^{\mathrm{c}} \\
8^{\mathrm{c}}\end{array}$ & & $\begin{array}{l}0.40 \\
0.96\end{array}$ & & $\begin{array}{r}47 \\
113\end{array}$ \\
\hline
\end{tabular}

a In experiment 1, estimates were obtained by multiplying mean number of hybrids per stomach for each sample period by the estimated number of largemouth bass (118) and summing the products over time. In experiment 2 , jaw tags accumulated in largemouth bass stomachs from the time of hybrid consumption until capture. Thus, each estimate was inherently cumulative and derived by simply multiplying the mean number of tags per stomach by the population estimate of predators.

b Hours after night stocking.

c These fish are the same fish that provided the 24- and 48-hour samples for the night-stocked group.

hybrids were eaten by largemouth bass (Table $3)-18 \%$ more than were stocked. These overestimates may have resulted from our intensive sampling program during which nearly $50 \%$ of the largemouth bass population was stomachpumped over 48 hours. Also, intensive inshore sampling with an electroshocker in this small pond may have caused some predators to remain offshore, isolated from stocked hybrids; we found it increasingly difficult to sample desired numbers of largemouth bass during experiments (see Table 3). If these two factors reduced the number of active predators, then multiplying mean number of hybrids per stomach by the entire largemouth bass population would have overestimated the number lost to predation.

\section{Hybrid Survival in Lakes}

We stocked tiger muskellunge into Acton and Stonelick lakes during the day at one location in each lake. Predation by largemouth bass began within 8 hours of stocking and continued to increase through day 3. Mean number of hybrids per stomach gradually declined through day 28 in Acton Lake and day 43 in Stonelick
Lake (Fig. 1). From our estimates, largemouth bass predators consumed $45 \%$ of all tiger muskellunge in Stonelick Lake and $26 \%$ in Acton Lake, while total mortality over 40 days (based on the slopes of catch curves) exceeded $95 \%$ in both lakes (Fig. 1).

The precipitous rise in predation by largemouth bass over the first 3 days after stocking correlated well with movement patterns of hybrids. On day 1 , tiger muskellunge were found close to stocking sites and along opposite shorelines (Fig. 2). By day 3, they were distributed throughout both lakes; rates of movement (meters/day) were similar in both lakes. As tiger muskellunge moved throughout each lake, they were exposed to a progressively larger fraction of the largemouth bass population. Higher first-day predation rates in Stonelick Lake than in Acton Lake can be related to the proximity of stocking sites to prime largemouth bass habitats. In Acton Lake, few largemouth bass were found near the stocking site at the shallow upper end of the lake, whereas in Stonelick Lake, hybrids happened to be stocked in an area of high predator density. Temporal trends of predation by largemouth bass on tiger muskel- 


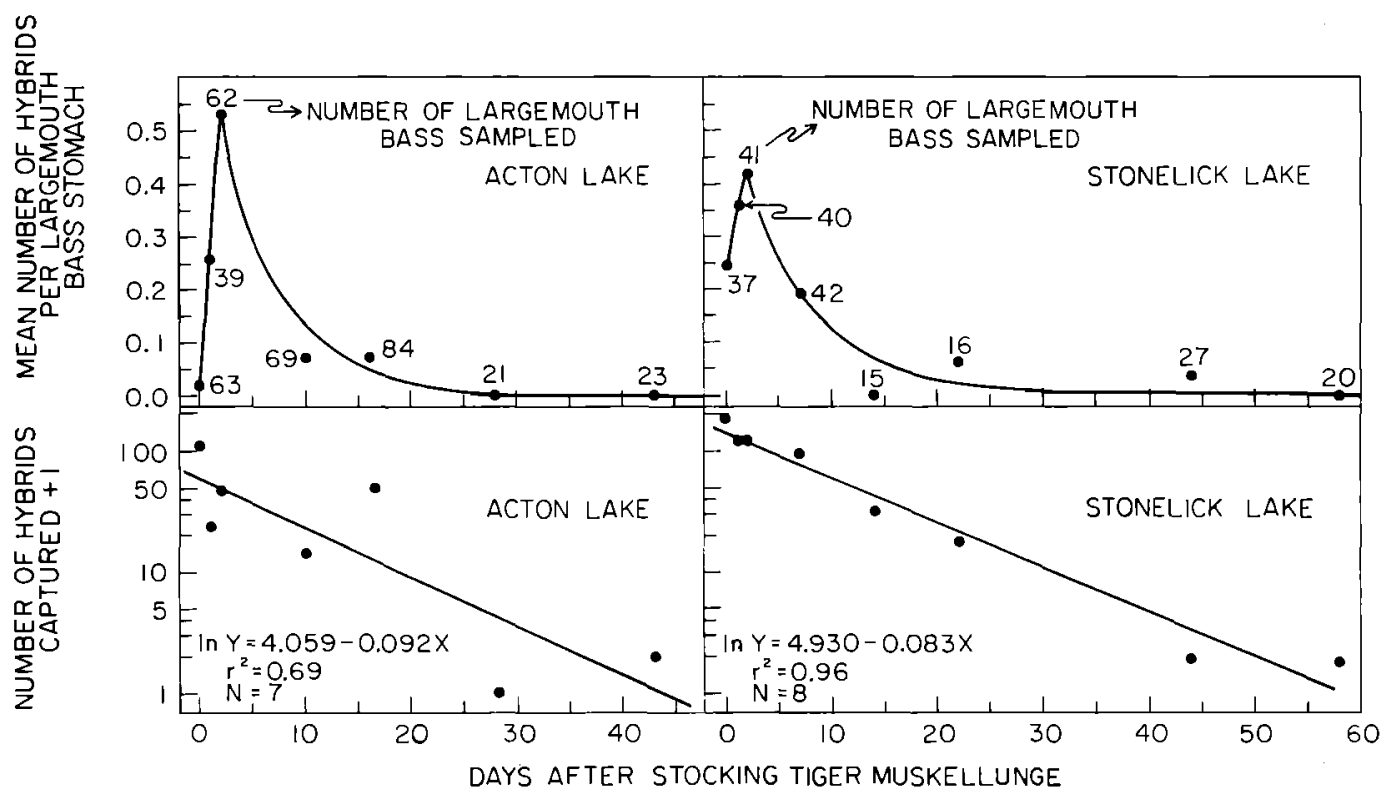

F1GURE 1.-Upper panels: temporal trends in predation by largemouth bass on stocked tiger muskellunge in Acton and Stonelick lakes. Curves were fitted by inspection. Lower panels: number ( $Y$ ) of tiger muskellunge sampled by electrofishing versus days (X) following their release.

lunge in these two reservoirs resulted from the distribution of largemouth bass and movement patterns of hybrids.

Largemouth bass were size-selective in their choice of prey. For those length classes that could eat tiger muskellunge, the smaller the size of hybrids, the smaller the size class of largemouth bass that preyed most heavily upon them (Figs. 3 and 4).

\section{Discussion}

Nearly all stocked tiger muskellunge were eliminated from Acton and Stonelick lakes after 45 days. Beyond this date, no largemouth bass contained hybrids and only two stocked fish were captured during extensive sampling. Apparently, a substantial portion of hybrid mortality in these two lakes resulted from transportation and thermal stress and predation by largemouth bass.

For hybrids held in a predator-free net, we found that nearly $10 \%$ in Acton Lake and 30\% in Stonelick Lake died within 48 hours poststocking. Comparisons of numbers of dead hybrids recovered 1 hour after stocking suggests that stress-related mortality was greater in Stonelick Lake than in Acton Lake. While these data cannot be used to estimate rates of mortality, they suggest the importance of stress in influencing survival.

This differential stress-related mortality between lakes seems related to thermal shock. Hybrids stocked into Stonelick Lake were subjected to the greatest temperature differential at stocking ( $9.5 \mathrm{C}$ without tempering) as well as the highest lake temperature at $30.5 \mathrm{C}$ (Table 1 ), which is near the upper lethal limit for tiger muskellunge (Scott 1964; Bonin and Spotila 1978).

Though our data indicate that predation mortality of hybrids was substantial, we believe these estimates were conservative. First, fish in largemouth bass stomachs were counted as tiger muskellunge only if they could be positively identified from a characteristic body part, such as a jaw. Second, our curve-fitting in Fig. 1 was conservative for we simply connected the data points for nights 1 through 3 and fit a descending curve to subsequent points. With this technique, we estimated a declining predation rate after day 3. If predation rates on days 4 through 7 (days for which we have no samples) were equal to or greater than those on day 3 , our estimates of mortality due to largemouth 


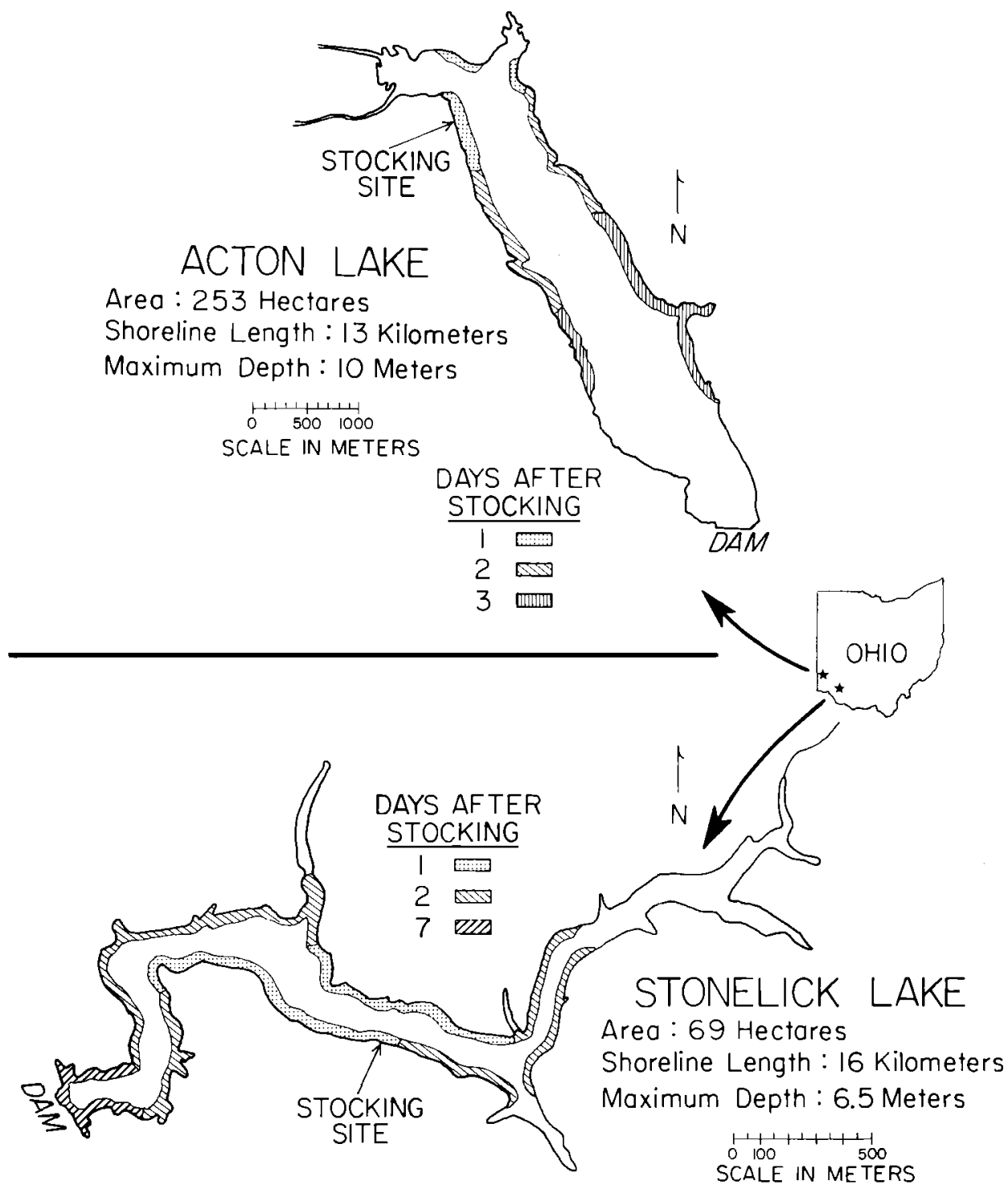

FigUre 2.-Distribution through time of tiger muskellunge after their release into Acton and Stonelick lakes, as determined by electrofishing and seining.

bass predation would have been considerably higher. Other potential sources of hybrid mortality include disease (Belusz 1978), parasites (Snow 1974, 1978), starvation, or emigration (Snow 1974, 1978). Our observations suggest that these sources of mortality were not important. Thermal stress and predation seem the most likely causes of the loss of tiger muskellunge, even though our estimates of these vari- ables were not sufficient to explain all of the mortality in either lake.

\section{Stocking Practices to Improve Survival}

Night stocking does not appear to reduce predation mortality. However, given tiger muskellunge behavior at stocking, this procedure might provide hybrids with a rest period, thus reducing mortality due to stress (Belusz 1978). 


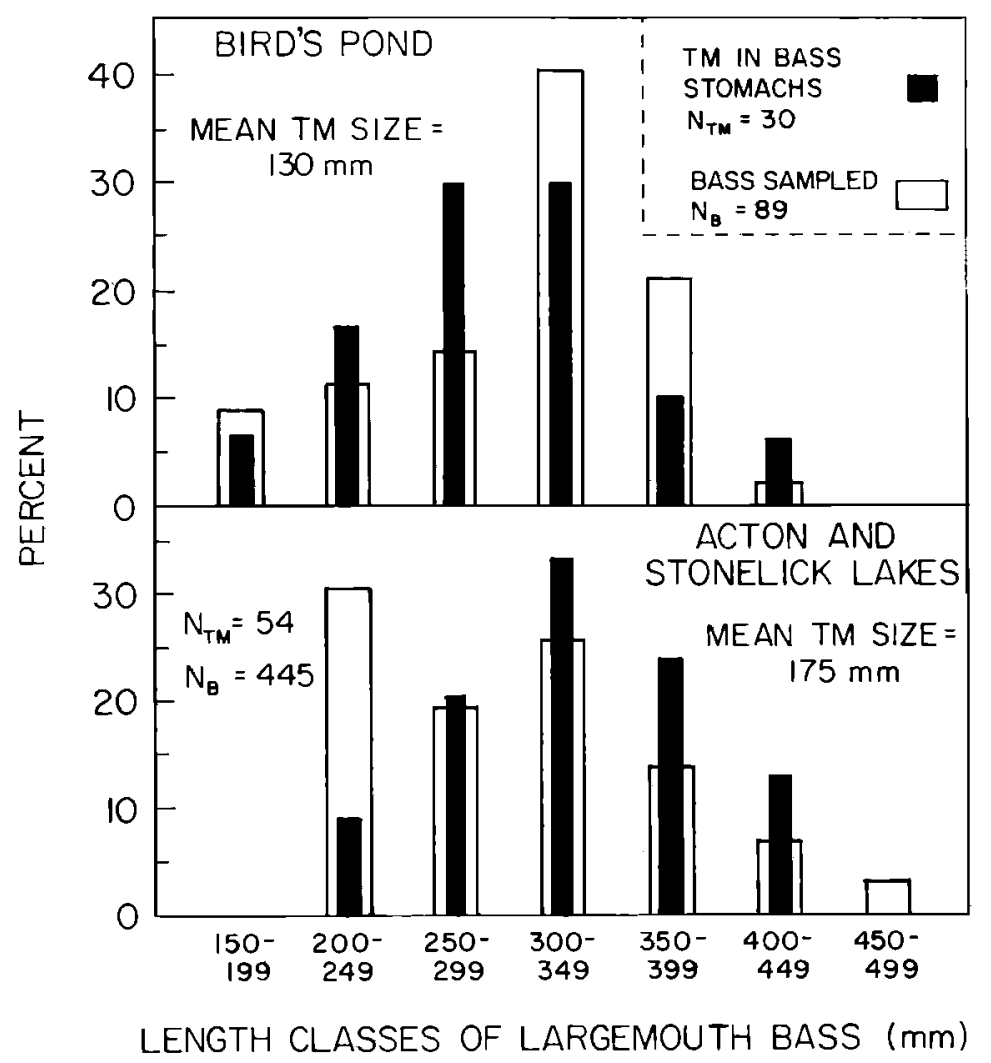

FIGURE 3.-Length frequency distribution of largemouth bass and the percent of tiger muskellunge (TM) consumed by predators of each length class, for all poststocking samples combined. Solid bars projecting above open bars indicate predation by largemouth bass at levels exceeding that which would be expected if all size classes fed randomly on hybrids.

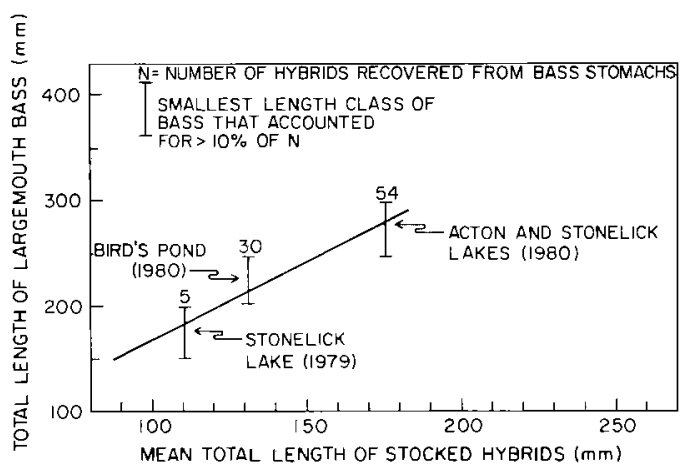

FIGURE 4.-Relation between largemouth bass size and vulnerable sizes of stocked tiger muskellunge hybrids in Bird's Pond and Acton and Stonelick lakes. Vertical lines represent the smallest length class $(50-\mathrm{mm}$ interval) of largemouth bass that accounted for more than $10 \%$ of the total number of hybrids recovered from predator stomachs during the sample period following any one stocking. The line was fitted by inspection.
Work with rainbow trout Salmo gairdneri (Barton et al. 1980) and chinook salmon Oncorhynchus tshawytscha (Strange and Schreck 1978) suggests that high blood cortisol levels (resulting from stocking) do not return to normal until 1 week poststocking. These studies are especially pertinent for they demonstrate a positive relationship between cortisol levels and susceptibility to a secondary stressor (crowding). Thus, while night stocking may reduce stress for about 8 hours, its contribution to reduced mortality in the long term remains suspect.

Because temperature shock and predation may account for a substantial portion of hybrid mortality, stocking success could be improved in several ways. At some size, hybrids become invulnerable to predators. Based on previous stocking results, $250-\mathrm{mm}$ tiger muskellunge should be invulnerable to all but the largest 
(over $400 \mathrm{~mm}$ ) largemouth bass (see Fig. 4) which seldom are more than $15 \%$ of those over $200 \mathrm{~mm}$ (K. Fritz, Ohio Division of Wildlife, Columbus, personal communication, data from 13 reservoirs in Ohio). Hess (1980) also found that losses to largemouth bass predation appear small when hybrids are stocked at sizes approaching $250 \mathrm{~mm}$. In related work, Keith and Barkley (1971) found that stocked rainbow trout greater than $230 \mathrm{~mm}$ were only eaten by largemouth bass greater than $400 \mathrm{~mm}$. These observations coupled with our data suggest that $250-\mathrm{mm}$ hybrids would be relatively free from predation, at least by largemouth bass. If predator populations are dominated by large esocids or walleyes Stizostedion vitreum, stocked fish should be even larger than $250 \mathrm{~mm}$. The size distribution of the primary predators in any lake should be determined before a specific size is recommended for stocking.

To rear $250-\mathrm{mm}$ tiger muskellunge, hatcheries must retain fish through September and into October, but delayed stocking has several advantages. Many midwestern reservoirs and lakes are stratified in late summer, with little or no oxygen in the hypolimnion. At this time, largemouth bass are more likely to concentrate in shallow, inshore waters where stocked tiger muskellunge would be released. After fall overturn, when the entire water column becomes oxygenated, both largemouth bass and tiger muskellunge can disperse, reducing encounters of predators with prey. In addition, at temperatures below $25 \mathrm{C}$, food consumption of largemouth bass, and therefore predation on hybrids, is reduced (Niimi and Beamish 1974). Although no information exists for tiger muskellunge, physiological optima for northern pike lie in the range of 18-25 C (Casselman 1978). If tiger muskellunge are similar, stocking at temperatures less than $25 \mathrm{C}$ will reduce stress on the introduced hybrids. For a variety of reasons, then, fall stocking should increase survival of tiger muskellunge.

In summary, to maximize their survival in lakes where largemouth bass are the primary predator, tiger muskellunge should be reared to $250 \mathrm{~mm}$ (to reduce predatory mortality) and stocked in mid to late October (to minimize thermal stress and reduce encounters with predators) when their own prey are of the appropriate size (Gillen et al. 1981) and density. The physicochemical enviromment, the size dis- tribution and species composition of the predator populations, and the density and size distribution of potential prey all should be evaluated before stocking programs are developed for a lake.

\section{Acknowledgments}

We thank everyone associated with the Aquatic Ecology Laboratory, The Ohio State University, for help during the field seasons of 1979 and 1980 . We appreciate the support and cooperation of the Ohio Department of Natural Resources; D. B. Apgear acted as an effective liaison between us and the Department. P. J. Pfister and P. Keyes (Kincaid Fish Farm) contributed time, effort, and tiger muskellunge for our experiments; Charles H. Bird allowed us to use his private pond for experimental work. We thank L. C. Belusz, L. Hess, B. Johnson, C. Lakes, K. Laub, D. Maloney, and H. E. Snow for their constructive reviews of an early draft of this manuscript. This research was supported in part by funds from the Federal Aid in Fish Restoration Act under Dingell-Johnson Project F-57-R.

\section{References}

Barton, B. A., R. E. Peter, and C. R. Paulencu. 1980. Plasma cortisol levels of fingerling rainbow trout (Salmo gairdneri) at rest, and subjected to handling, confinement, transport, and stocking. Canadian Journal of Fisheries and Aquatic Sciences 37:805-811.

Belusz, L. C. 1976. The use of isolation coves in assessing muskellunge stocking mortality. Proceedings of the Annual Conference Southeastern Association of Game and Fish Commissioners 29:251-253.

Belusz, L. C. 1978. An cvaluation of the muskellunge fishery of Lake Pomme de Terre and efforts to improve stocking success. American Fisheries Society Special Publication 1 1:292-297.

Bonin, J. D., And J. R. Spotila. 1978. Temperature tolerance of larval muskellunge (Esox masquinongy Mitchill) and $F_{1}$ hybrids reared under hatchery conditions. Comparative Biochemistry and Physiology A, Comparative Physiology 59:245-248.

Casselman, J. M. 1978. Effects of environmental factors on growth, survival, activity, and exploitation of northern pike. American Fisheries Society Special Publication 11:114-128.

Foster, J. R. 1977. Pulsed gastric lavage: an efficient method of removing the stomach contents of live fish. Progressive Fish-Culturist 39:166-169.

Gillen, A. L., R. A. Stein, and R. F. Carline. 1981. Predation by pellet-reared tiger muskellunge on minnows and bluegills in experimental systems. 
Transactions of the American Fisheries Society 110:197-209.

GRAFF, D. R. 1978. Intensive culture of esocids: the current state of the art. American Fisheries Society Special Publication 11:195-201.

Hess, L. 1979. Small impoundment investigation: evaluation of existing small impoundment esocid populations. West Virginia Department of Natural Resources, Federal Aid in Fish Restoration Project F-23, Charleston, West Virginia, USA.

Hess, L. 1980. Small impoundment investigation: evaluation of existing small impoundment esocid populations. West Virginia Department of Natural Resources, Federal Aid in Fish Restoration Project F-23, Charleston, West Virginia, USA.

Hesser, R. B. 1978. Management implications of hybrid esocids in Pennsylvania. American Fisheries Society Special Publication 11:302-307.

Johnson, L. D. 1976. Statewide fishery research: development of improved muskellunge stocking procedures. Wisconsin Department of Natural Resources, Federal Aid in Fish Restoration Project F-83, Madison, Wisconsin, USA.

Johnson, L. D. 1978. Evaluation of esocid stocking program in Wisconsin. American Fisheries Society Special Publication 11:298-301.

KeIth, W. E., And S. K. Barkley. 1971. Predation of stocked rainbow trout by chain pickerel and largemouth bass in Lake Ouachita, Arkansas. Proceedings of the Annual Conference Southeastern Association of Game and Fish Commissioners 24:401-407.

Nimi, A. J., and F. W. H. Beamish. 1974. Bioenergetics and growth of largemouth bass (Micropterus salmoides) in relation to body weight and temperature. Canadian Journal of Zoology $52: 447-456$.
Orme, L. E. 1978. The status of coolwater fish diets. American Fisheries Society Special Publication $11: 167-171$.

Ricker, W. E. 1975. Computation and interpretation of biological statistics of fish populations. Fisheries Research Board of Canada Bulletin 191.

Schrouder, J. D. 1973. Muskellunge management in Michigan. Michigan Department of Natural Resources Technical Report 73-31, Ann Arbor, Michigan, USA.

Scotr, D. P. 1964. Thermal resistance of pike (Esox lucius L.), muskellunge ( $E$. masquinongy Mitchill), and their $F_{1}$ hybrid. Journal of the Fisheries Research Board of Canada 21:1043-1049.

SEABURG, K. G. 1957. A stomach sampler for live fish. Progressive Fish-Culturist 19:137-139.

SNow, H. E. 1974. Effects of stocking northern pike in Murphy Flowage. Wisconsin Department of NaturaI Resources Technical Bulletin 79.

SNOw, H. E. 1978. A 15-year study of the harvest, exploitation and mortality of fishes in Murphy Flowage, Wisconsin. Wisconsin Department of Natural Resources Technical Bulletin 103.

Strange, R. J., and C. B. Schreck. 1978. Anesthetic and handling stress on survival and cortisol concentration in yearling chinook salmon (Oncorhynchus tshawytscha). Journal of the Fisheries Research Board of Canada 35:345-349.

Weithman, A. S. 1975. Survival, growth efficiency, preference, and vulnerability to angling of Esocidae. Master's thesis. University of Missouri, Columbia, Missouri, USA.

Weithman, A. S., AND R. O. Anderson. 1977. Survival, growth, and prey of Esocidae in experimental systems. Transactions of the American Fisheries Society 106:424-430. 